PF 2019 (LXXIV): 135-154

\author{
HALINA KARAŚ \\ Instytut Języka Polskiego \\ Uniwersytet Warszawski \\ ul. Krakowskie Przedmieście 26/28, 00-927 Warszawa \\ tel. +48 (22) 5521021 \\ e-mail: h.a.karas@uw.edu.pl
}

\title{
W TEJ RZEKI. MIEJSCOWNIK LICZBY POJEDYNCZEJ RZECZOWNIKÓW ŻEŃSKICH TWARDOTEMATOWYCH W GWARACH POLSKICH NA LITWIE
}

Słowa kluczowe: polszczyzna północnokresowa, fleksja, rzeczownik, miejscownik, synkretyzm.

Keywords: Polish language in the North-Eastern Borderlands, inflection, noun, the locative case, syncretism.

\section{W TEJ RZEKI. THE LOCATIVE CASE SINGULAR IN HARD-STEM FEMININE NOUNS IN POLISH DIALECTS IN LITHUANIA}

\begin{abstract}
The paper aims at discussing the forms of the locative case singular in hardstem feminine nouns in Polish dialects in the Ignalina and Zarasai regions in Lithuania (at the border with Belarus and Latvia). It focuses on forms that have not been yet examined in linguistic works of reference and are unknown in other dialectal regions of Lithuania, namely the forms of the locative case that are syncretic with the genitive case, e.g. $w$ tej rzeki, pierwszy $w$ rodziny, na swojej skóry.
\end{abstract}

Celem niniejszego artykułu jest omówienie form miejscownika liczby pojedynczej rzeczowników żeńskich twardotematowych występujących w gwarach polskich na Litwie w rejonach ignalińskim i jezioroskim graniczących z Białorusią i Łotwą. Uwagę zwracają zwłaszcza nieopisane w literaturze przedmiotu, niepoświadczone na innych obszarach gwarowych na Litwie i na całych Kresach 
Wschodnich formy miejscownika synkretyczne z dopełniaczem, typu $w$ tej rzeki, na blaszki takiej, pierwszy w rodziny, na swojej skóry, na gitary grała.

Polszczyzna na wspomnianym pograniczu litewsko-łotewsko-białoruskim w jego części głównie południowej została uwzględniona w pracy Haliny Turskiej (Turska 1939/1995), a ostatnio w monografii mojego autorstwa (Karaś 2017) oraz w licznych artykułach różnych badaczy polskich, litewskich i białoruskich (zob. m.in. Ananiewa 1974, 1982, 1983, Giułumianc, Czekman 1971; Karaś 2001, 2004, 2009, 2013; Kardelis 2016, Rutkowska 2004, 2013, 2015). Dlatego w artykule nie przedstawiam ani sytuacji językowej na tym obszarze, ani też stanu badań, odsyłając zainteresowanych do literatury przedmiotu.

Wszystkie przykłady miejscownika zostały wyekscerpowane z tekstów nagranych we wsiach ciągnących się wąskim pasem $w$ rejonie ignalińskim i jezioroskim wzdłuż granicy litewsko-białoruskiej i litewsko-łotewskiej. Tworzą one obszerny korpus tekstów gwarowych składający się z dwu podkorpusów: tekstów z rejonu ignalińskiego i jezioroskiego. Obejmują one razem ok. 250 stron komputeropisu, po 125 stron w obu częściach. Są to nagrania 54 informatorów, po $27 \mathrm{z}$ każdego rejonu. Próbka mowy każdego informatora liczy ok. 5-6 stron komputeropisu, choć niektóre są nieco mniejsze, inne nieco większe, w zależności od tego, jakim rodzajem nagrania dysponuję.

Łącznie w stworzonym dla celów badawczych korpusie tekstów odnotowano 368 przykładów form miejscownika rzeczowników żeńskich twardotematowych zakończonych na samogłoskę - $a$. Liczba przykładów jest prawie równa w obu podkorpusach: ignalińskim i jezioroskim, tj. wynosi odpowiednio 183 i 185 form lokatywnych. Uwzględniono tylko rzeczowniki żeńskie twardotematowe, w związku z tym pominięto te, które w omawianych gwarach reprezentują inny typ odmiany miękkotematowej, mimo iż w języku ogólnym właściwa jest im deklinacja twardotematowa, por. np. pšy Polščy, v Łatv'iji; ogp. przy Polsce, w Lotwie.

W odnotowanych przykładach form lokatywnych występuje przede wszystkim charakterystyczna dla rzeczowników żeńskich twardotematowych zakończonych na samogłoskę - $a$ ogólnopolska końcówka -e. Dodatkowym wykładnikiem tego przypadka są alternacje tematyczne typowe dla polszczyzny ogólnej:

- spółgłoska twarda - spółgłoska miękka / zmiękczona, por. np. v - v' (v głov'e Bej.IK[35]); $m$ - m' (po mam'e Pac.HS[25]); $\downarrow$ - l’ [l] (f škole Rem.AC[29]; f stodole Strył.KG[33]); $d-z^{\prime}$ [3'\| 3"] (v voz’e Strył.JG[34]); $n-n$ (v roz’ine Strył.KG[33]); $t-c ́ c$ [c' $\left.\| c^{\prime \prime}\right]$ (fxac"e Kaln.IS[31]);

- w odniesieniu do rzeczowników, których temat fleksyjny kończy się na spółgłoskę tylnojęzykową - $k-,-g-$, odpowiednia alternacja $k-c, g-3^{-}$, por. np. na tej žečce Bej.IK[35]; pšy Polsce Czep.BD[24]; na gospodarce Gak. WP[12]; na v'osce; na łonce Pac.HS[25]; na monce Tryk.WS[32]; po droze Pruc.ZS[21]; $v$ noze Weł.TS[35]. 
Obocznie do końcówki -e funkcjonują końcówki wariantywne powstałe w wyniku różnorodnych procesów fonetycznych, takich jak: tzw. akanie, czyli wymowa nieakcentowanego $e$ jako $a$; lub tzw. ikanie, tj. wymowa nieakcentowanego $e$ jako $i / y$ czy jako rezultat interferencji języka litewskiego artykulacja $e$ jako $\stackrel{a}{e}$, czyli głoska $e$ obniżona, szeroka, bliska $a$, ale bardziej otwarta, tak jak w języku litewskim (zob. Karaś 2002: 136-137; Karaś 2017: 271-275). Wariantami fonetycznymi powstałymi w wyniku wymienionych procesów zachodzących w polszczyźnie północnokresowej są zatem końcówki:

- $\boldsymbol{a}$ (wynik tzw. akania), por. np. po łac"ińa naboženstva Czep.BD[24]; na ńiv'a Gak.WP[12]; pšy krov'a Mej.JS[42]; v głov'a Gram.MK[26]:

$-e$ (interferencja języka litewskiego), por. np. fxac'e Mag.JK[34]; bajka že ońi $v$ Lit'v'e Maz.SM[23];

- $\boldsymbol{i}$ po spółgłosce miękkiej /-y po spółgłosce stwardniałej (wynik tzw. ikania), por. np. po kolen'z"i Kaln.IS[31]; na v'oscy Trycz.LT[32]; na gužy Stal.JG[33].

Pojawia się też $\mathrm{w}$ obu podkorpusach tekstów pewna liczba form miejscownika z końcówką -e, ale bez typowych dla polszczyzny oboczności tematycznych, por. np. pšy curk'e; $u$ nas u Gryškofk'e Gram.MK[26]: f Polsk'e Strył.KG[33]; po vaservag'e Tryk.ZS[28]; na gurk'e Duk.AS[46]; f Polsk'e Imb.WP[39]; v ap'ilink'e Muk.JW[25]; na tačk'e Smołw.AS[39]; na kšyžovatk'e; v R'ıg'e Suw.HK[29].

Inna końcówka, poza -e i jej wariantami fonetycznymi, która występuje $\mathrm{w}$ badanym materiale, to nieopisywana dotąd $\mathrm{w}$ literaturze przedmiotu poświęconej fleksji w polszczyźnie kresowej, końcówka - $y$ (po spółgłoskach twardych) / -i (po spółgłoskach $k^{\prime}, g^{\prime}$, tj. funkcjonalnie / historycznie twardych). Oznacza to formy tożsame $\mathrm{z}$ dopełniaczem analizowanych rzeczowników, a więc ilustruje nienotowany dotąd w języku polskim na Kresach typ synkretyzmu: miejscownik - dopełniacz lp. rzeczowników żeńskich twardotematowych.

Dane liczbowe i procentowe dotyczące końcówki -e i jej wariantów oraz końcówki $-y /-i$ zawiera tabela nr 1 .

Tabela nr 1. Liczba form Msc. lp. rzeczowników żeńskich twardotematowych $\mathrm{w}$ tekstach $\mathrm{z}$ rejonu ignalińskiego i jezioroskiego

\begin{tabular}{|c|c|c|c|c|c|}
\hline Obszar & $\begin{array}{l}\text { Liczba form } \\
\text { ogp. z końc. } \\
-e\end{array}$ & $\begin{array}{l}\text { Liczba kres. } \\
\text { wariantów } \\
\text { fon. końc. }-e \\
(-a,-i,-y,-e)\end{array}$ & $\begin{array}{l}\text { Liczba } \\
\text { form kres. } \\
\text { z -e z nogp. } \\
\text { alternacją tem. }\end{array}$ & $\begin{array}{l}\text { Liczba form } \\
\text { kresowych } \\
\text { (Msc.=D.) }\end{array}$ & $\begin{array}{l}\text { Razem } \\
\text { formy Msc. } \\
\text { lp. rzecz. } \dot{z} . \\
\text { twardotem. }\end{array}$ \\
\hline Ignaliński & $122(66,7 \%)$ & $36(19,7 \%)$ & $7(3,8 \%)$ & $18(9,8 \%)$ & 183 \\
\hline Jezioroski & $88(47,5 \%)$ & $47(25,4 \%)$ & $14(7,6 \%)$ & $36(19,5 \%)$ & 185 \\
\hline Razem & $210(57,1 \%)$ & $83(22,6 \%)$ & $21(5,7 \%)$ & $54(14,7 \%)$ & 368 \\
\hline
\end{tabular}

Źródło: Opracowanie własne. 
Dane zawarte w powyższej tabeli wskazują na nie tak rzadki typ tożsamych z dopełniaczem form lokatywnych - 54 przykłady, tj. 14,7\% wszystkich form miejscownika lp. femininów twardotematowych. Przeważają oczywiście formy ogólnopolskie z końcówką -e i obocznościami tematycznymi - 210, tj. 57,1\% wszystkich odnotowanych form lokatywnych analizowanych rzeczowników. Gdy jednak uwzględnimy też formy z fonetycznymi wariantami końcówki -e powstałymi na skutek północnokresowych procesów fonetycznych, to przewaga ta znacznie wzrasta - razem 293 przykłady, tj. 79,8\% zgromadzonych form. Marginalne są formy nawiązujące do języka rosyjskiego i do gwar białoruskich pasa północno-wschodniego, tylko $\mathrm{w}$ odniesieniu do rzeczowników twardotematowych, których temat fleksyjny kończy się na spółgłoskę tylnojęzykową $-k$ - lub - $g$-, tj. z końcówką - $e$, ale bez alternacji będących historycznie wynikiem II palatalizacji spółgłosek tylnojęzykowych (z alternacją nogp. $k-k^{\prime}, g-g^{\prime}$ ), czyli typ curk'e, $v$ R'ıg'e - 21 przykładów, tj. 5,7\% zbioru analizowanych form lokatywnych.

Widać też znacznie większy udział w polszczyźnie jezioroskiej osobliwych form miejscownika równych dopełniaczowi rzeczowników żeńskich twardotematowych niż w odmianie ignalińskiej, dwukrotny - 36 takich przykładów z rejonu jezioroskiego (19,5\% wszystkich miejscowników w podkorpusie jezioroskim) wobec 18 egzemplifikacji z rejonu ignalińskiego (9,8\% przykładów z podkorpusu ignalińskiego).

Polszczyznę ignalińską charakteryzuje znacznie większy udział form tożsamych z ogólnopolskimi (122 formy, tj. 66,7\%) niż jezioroską ( 88 form, tj. 47,5\%), w której przeważają formy kresowe (łącznie 98 form, tj. 52,5\% podkorpusu jezioroskiego).

Poniżej przytaczam wyekscerpowany z tekstów gwarowych materiał, tj. formy miejscownika liczby pojedynczej rzeczowników twardotematowych żeńskich. Formy tożsame $\mathrm{z}$ ogólnopolskimi, tj. $\mathrm{z}$ końcówką -e i jej wariantami fonetycznymi podaję na ogół z przyimkiem lub z niewielkim kontekstem, wskazującym na ten przypadek, natomiast nieco szerszy kontekst przytaczam przy osobliwych formach $\mathrm{z}$ końcówką $-y /-i$, tj. synkretycznych $\mathrm{z}$ dopełniaczem lp. 


\section{Formy miejscownika lp. rzeczowników żeńskich twardotematowych $\mathrm{z}$ końcówką - $e$ i alternacją tematyczną: spółgłoska twarda - spółgłoska miękka (funkcjonalnie miękka)}

\subsection{Przykłady $\mathrm{z}$ gwar polskich $\mathrm{w}$ rejonie ignalińskim:}

na tej žečce; $v$ b’iblotece; $f$ Pol'sce; $v$ głov'e; $f$ trav'e Bej.IK[35]; na Lotv'e; $v$ V'isag’ine; pšy Polsce; čy $f$ pažel/ $f$ paže Czep.BD[24]; na mondolince; $f$ škole muzyčnej Gaj.SK[36]; na vojnee, na emerytuže Gaj.MK[25]; na gospodarce; na v'osce; po vojńe; na nivie; teras u Litv'e Gak.WP[12]; fkoperc'e; f klińice; v našej v'osce; $f$ Pol'sce, $v$ droze, na starej Litv'e; $u$ trav'e; $f$ svojej strońe Gram.MK[26]; na robôc'e; pa Littv'e Mej.JS[42]; na tamtej struone; v głov'e Mej.TM[36]; na v'osce; na łonce; $f$ Po l'sce; $f$ tej xatečce, $v$ droze; po podłoze; $v$ roz ïńe; $v$ drug'ej strońe; po mam'e; $f$ škole; Pac.HS[25]; pšy Polsce; $f$ tej rozmov'e Pruc.GS[26]; po droze; $f$ Pol'sce Pruc.ZS[21]; na ferm'e; na tej strońe; na s'c'eńe; $f$ Polsce Pusz.SK[23]; na v'ôsce; pšy Polsce; na droze; v vojńe; $f$ škole Rej.WM[22]; u ks'onsce; $f$ Polsce; $v$ Litv'e; fškole Rem.AC[29]; v voz'e; f Polsce; f paže Strył.JG[34]; na droze; v roz’ine; $f$ stodole Strył.KG[33]; na vojence; $v$ roz ińe; $f$ Pôlsce Szmel.PL[19]; na łavecce; po butelce; f pšerv'e; na kanap'e; f kturej strone Szuł.NK[30]; na pral'ce; pa kolejce; $f$ tej povosce; $v$ gospodarce; po droze, $v$ Ĺitv'e; $v$ głov'e; Śmil.EP[15]; na monce; pā vojne Tryk.WS[32]; na mašyńe, na brame; $v$ Borufce; $v$ jednej xac'e; pa droze; $f$ škole Und.WS[33]; na gurce, $v$ roz'ine; $v$ našej v'osce; $v$ Moskv'e, $v$ Ryze; v noze Weł.TS[35]; na v'elk'ej łonce; na takaj desečce; v'osce Zyg.WT[34].

\subsection{Przykłady $z$ gwar polskich $w$ rejonie jezioroskim}

na guže; na plitce; na plic'eš, na jęz'ežel jez'ora Bach.JP[24]; po našej droze; $f$ každej xac'e, po našej strońe Czepul.KS[23]; po vojńe; po droze; po rozmov'e, $f$ parc'e tej; $f$ tamtej strońe Duk.AS[46]; $f$ tamtej vojńe; $f$ Tule; $f$ tej |komnac'e; $f$ Polsce, v Ĺit'v'e Gir.AP[18]; v Ĺitv'e, $f$ Pol'sce Jez.BK[30]; na svojej mašyńe; na noze, v jakaj roz'ine Jez.JW[34]; $v$ voz"e, na tej strońe, po tej droze; po kolen'z"e; $f$ turm'e; f Kłajp’ez"e, fxac"e Kaln.IS[31]; pšy Ĺitv'e Mag.BP[31]; na guže, v Moskv'e; $v$ dolińe, $f$ škole, po jakaj pšyčyńe Mag.JK[34]; $f$ kab’ine; $f$ xac'e Min.JJ[35]; na f'erm'e; na ambońe; na głov'e Muk.JW[25]; f tamtej vojńe Nar.NS[20]; na gazec'e; na guže; na Litv'e; $v$ totv'e, fškole, f c'urm'e; f p'eršej vojńe, po głov'e Now.WK[20]; $f$ tamtej vojne; Ows.AO[17]; na mašyńe, na ferm'e, $v$ Ĺitv'e; $f$ Polsce po vojne; po połov'e Rom.RV[24]; na oreńz"e, v roz"ine, v Litv'e, f tej gumńe, po pułov'e, po 
koleńz'e Smołw.AS[39]; na f'erm'e Stal.JG[33]; na guže Suw.HK[29]; na tej jez'eže, f Polsce Szaw.WJ[[34]; f xac'e Szuk.HD[22].

\section{Formy miejscownika $\mathrm{z}$ końcówką -e w postaci wariantu $-a,-\stackrel{a}{e}$}

\subsection{Końcówka $-\stackrel{a}{e}$}

na na gžyv'e Bej.IK[35]; na bramcé Gaj.SK[26]; p̌̌y krov'e Mej.JS[42]; s'ostra $v$ Ryze Weł.TS[35]; na xac'e Bach.JP[24]; $v$ mojej błoc'e Bach.JP[24]; $f$ šaf'e; $f$ xac'e Bach.JP[24]; $v$ Litv'e Gir.AP[18]; $v$ Litv'e Imb.WP[39]; $f$ xac'e ${ }^{\prime a}$ Mag.JK[34]; $v$ Lit'v'e Maz.SM[23]; była až u Kł|ajp'ez'e; v głov'e Gram.MK[26].

\subsection{Końcówka - $a$}

\subsubsection{Przykłady z gwar polskich rejonu ignalińskiego:}

na Litv'a; po łac"ińa; na Litv'al juš i po V'ilanščyz"ńa Czep.BD[24]; na ńiv'a Gak.WP[12]; p̌̌y krov'a Mej.JS[42]; v z'im'a, pa tej strońa Mej.TM[36]; pšy Pôl'sca Pac.HS[25]; f tej v'ôsca Pruc.ZS[21]; f Pol'sca Pusz.SK[23]; v v'ôsca Rej. WM[22]; fškôla Szuł.NK[30]; po kolejca Śmil.EP[15]; na drugaj strońa, pa vojńa Tryk.ZS[28]; v Moskv'a; v noza Weł.TS[35].

\subsubsection{Przykłady z gwar polskich rejonu jezioroskiego}

$f$ školā, $f$ xac'a Bach.JP[24]; $f$ xac'a Gir.AP[18]; $f$ xac'a; $f \mid k o m n a c ' a, f$ Kłajp'ez’a Imb.WP[39]; na noza, $f$ škola Jez.JW[34]; $f$ škol’a Kaln.IS[31]; na tej strońa; na plic'a Mag.MN[20]; na kšyžufca Maz.SM[23]; v Ĺitv'a, $f$ každej xac'a Min.JJ[35]; na vojńa; po tej błoc'a, f turm'a, fškol'a Muk.JW[25]; na f'erm'a, po vojńa Nars.SM[20]; $v$ gazec'a, $v$ mog'il'a; $v$ Lotv'e Now.WK[20]; v vojńa, $f$ turm'a, pšy Litv'a Ows.AO[17]; v Litv'a Smołw.AS[39]; na tej voz'a, poza droza, po voz’a Suw.HK[29]; $f$ škola Stal.JG[33].

\subsection{Końcówka $-i /-y$ ( $z$ alternacją tematyczną ogp.)}

po kol'en'z"i Kaln.IS[31]; na v'oscy Trycz.LT[32]; na gužy Stal.JG[33]. 


\section{Formy miejscownika rzeczowników zakończonych na $-k,-g$ z końcówką - $e$ bez alternacji $k-c, g-d z$ (z alternacją nogp. $\left.k-k^{\prime}, g-g^{\prime}, r-r^{\prime}\right)$}

\subsection{Przykłady z rejonu ignalińskiego}

teras ona přy curk'e; $u$ nas u Gryškofk'e Gram.MK[26]: pracovat na strojk'e Rej.WM[22]; čšy lata přežyła f Pol’sk'e Strył.KG[33]; po vaservag'e Tryk.ZS[28]; grała na g'itar'e Zyg.WT[34].

\subsection{Przykłady $z$ rejonu jezioroskiego}

była na |M'inafk'e škoła; dom’ik beńz’i/ i o na gurk'e Duk.AS[46]; on teras $f$ Pol'sk'e; po litefsku rozmav'aju f Pol'sk'e Imb.WP[39]; juš pa papk'e po litefsku rozmav'ali Jez.BK; rob'itam v ap'ilink'e Mag.JK[34]; benz'i rob'ic' c'i v ap'ilink'e Muk. JW[25]; c'i f skajt'ikla benz'i rob'ic' / c'i v ap'ilink'e Muk.JW[25]; była f Polsk'e Smołw.AS[39]; v'ez'e na tačk'e Smołw.AS[39]; Smołvy byli f Polsk'e Smołw.AS[39]; škoła vo na kšyžovatk'e Suw.HK[29]; jedna v R'ıg'e była Suw.HK[29].

\section{Końcówka $-y \|-i$, tj. $-y$ (po spółgłoskach twardych) oraz $i$ (po funkcjonalnie twardych $\left.k^{\prime}, g^{\prime}\right)$}

Msc. lp. rzeczowników żeńskich twardotematowych może niekiedy przybierać końcówkę $-y /-i$, tj. mieć formę równą dopełniaczowi lp., a więc bez alternacji tematycznych właściwych temu przypadkowi w polszczyźnie ogólnej $k-c, g-3$ (tylko oboczności typowe dla dopełniacza lp. $k: k, g: g^{\prime}$ ): Formy te przytoczono w szerszym kontekście, by można było stwierdzić, iż są to niewątpliwie przykłady miejscownika lp. Większość kontekstów jest na tyle wyrazista, że nie budzą one wątpliwości, że mamy do czynienia z formami lokatywnymi. Niektóre jednak przykłady wymagają szerszego komentarza. Przykład (12) i (34) na skrzypki wskazuje na mianownik lp. ta skrzypka (por. błr. скрыпка ż.), podczas gdy forma ogólnopolska to plurale tantum te skrzypki. Przykład (17) u ławki to niewątpliwy miejscownik, przyimek $u$ pojawia się na miejscu ogp. $w$ jako rezultat procesu fonetycznego typowego dla gwar polskich na tym obszarze - wahań $v-u$, na skutek czego przyimek $v$ bywa często realizowany jako $u$ (zob. Karaś 2017, s. $262-$ 264). Podobnie w przykładzie (11) połączenie $u$ jednaj sukieneczki oznacza - co wynika z szerszego kontekstu - 'w jednej sukieneczce'. To samo zjawisko ilustrują 
przykłady (20) u duchowki oraz (44) u szlachtowaj fury. Z kolei przykłady (48) i (54) zawierają nazwy własne żeńskie zakończone na -ka: Borówka, Szunełka, które przybrały w miejscowniku lp. końcówkę -i po spółgłoskach funkcjonalnie (historycznie) twardych, dziś zmiękczonych $k^{\prime}, g^{\prime}$.

\subsection{Obszar ignaliński (18 przykładów)}

(1) zapomńelil že rency byli z'vonzane tam jak $z$ V'ilna ona ležałal nu pod Ostro Bramo/ $\mathbf{f}$ kapličck'i/ to ne roz'v'onzalil že daleko v'es'c'l tak i sxovali Bej.IK[35];

(2) p'ekła pšy mamy/ ja ješča i tutaj o p'ekła tamta laty k'ilka razy Bej.IK[35];

(3) ožax na leščyny v'iśi Gak.WP[12];

(4) z'em’i možğğs brac' v'ela xceš teš// a žeby tak z'e "u tyko na voski/ z'e vo pastav'iušy s'a dom// každy svoja z'em'a b’ežy/ a jak kto pšyšat Mej.JS[42];

(5) moj "ojca brat žańiušy s'e na Nemkiny Mej.JS[42];

(6) to pšyxozo frsyst'kel čakajo vo na łavečki tej Mej.TM[36];

(7) domovy byt xlep// na dambovyx/ na ajirax p’ekli/ na moyki Mej.TM[36];

(8) u mńe ruska p’ec jest// pa mamy/ mama umarta Mej.TM[36];

(9) teras my pa takej $\boldsymbol{m} \mid \mathbf{u z y k i}$ ńe zatancyylip Mej.TM[36];

(10) ja i sama trošečk'i na gitary grała u młodos"c"i Pup.JU[34];

(11) miłła moja u jednaj sukenečki co ty tam naryzykujiš Pup.JU[34];

(12) ja na skšypki grał/ na klarnec'a Strył.JG[34];

(13) na blaški tak'ej i p'eka u p'ecy Szuł.JS[33];

(14) pałka taka długa była/ i na pałki taka ješče pałka pšyv'onzana była Trykł.WS[32];

(15) z’v'onžy p'enkńe na patki długaj Trykł.ZS[28];

(16) jag był katlxos teš na strojki pracovał Trykł.ZS[28];

(17) s'eza u tafki/ žeby ńixt ńe dotulit sáa do mńe Und.HS[38];

(18) tutaj $\boldsymbol{v}$ voski fšstke luz'e tak'e pobožne Zyg.WT[34];

\subsection{Obszar jezioroski (36 przykładów)}

(19) monš pšyjexał/ s'ont na podmurufk'i i płakat Bach.JP[24];

(20) u duxofki fp'egby Bach.JP[24];

(21) ja sam na svojej skury ta pšešet Duk.AS[46];

(22) ona jedna $\boldsymbol{f}$ xatki žyji Gir.AP[18];

(23) moj "ojca brad v Datrojc'a/ v Ameryki Gir.AP[18];

(24) o|ńi zostali s"e na kvatery tam Grzeb.JN[31]; 
(25) tu renkaj suniiš/ pa garsteč $\boldsymbol{k}^{\prime} \boldsymbol{i}$ b'ežyš Grzeb.JN[31];

(26) na ščotki takaj ̌̌evńanaj vyčešy Grzeb.JN[31];

(27) ja ńe xcam na v́juski žyc' Imb.WP[39];

(28) my byliby teras $\boldsymbol{f}$ Pol'ski/ Pal'ak'i Imb.WP[39];

(29) tam na fabryki/ čegu/ rob’i tego plemanika žona Jez.BK[30];

(30) jes'li mne na roz’iny dobžel to ja ńa pojada do głodnaj Litvy Jez.BK[30];

(31) cos'c'i $v$ roziny beńz’i Jez.JW[36];

(32) xturen p'eršy v roziny Jez.JW[36];

(33) nu i spotykajo tam pšy bramax// davali tak i po butel'ki fšysk'i Jez.JW[36];

(34) tut ruža vam jest/ ten na nogi juš Jez.JW[36];

(35) on grał ład'ńel na skšypki grał/ on zafše f kłub'e grał Kaln.IS[31];

(36) tam myjon s"e pańi luz"i/ nog’i myju $f$ tej žeki Kaln.IS[31];

(37) z"es"en'c' luz" i f tej xatečki Kaln.IS[31];

(38) ona v voz"e pańi stoji/ statuja kam’ennal v voz"e/ v žeki// tam čšeba koło jej k'edy is" c" Kaln.IS[31];

(39) karz'inečka v jego na reyki Mag.MN[22];

(40) trajbulu|s'uk tak'i xoz'i v Rygi Mag.MN[22];

(41) v Ryg'e/ v Rygi stužył Mag.MN[22];

(42) ružy byva o v nogi ruža Mag.MN[22];

(43) byliby teras $\boldsymbol{f}$ Pol'ski Maz.SM[23];

(44) voz'ili u šlaxtovaj fury Nar.MS[20];

(45) v tafki tak jak obepšam s’a Now.WK[26];

(46) ja ńezdrova była/ tak pšyłožyła s'e i leža/ na kanapki tak Now.WK[26];

(47) do sons'atk'i pujz'e s'ońz'il s'ez’i na łafki Now.WK[26];

(48) moja ot ojca roz'ina/ to fšystk'e tam v Borufki/ Pol'ak'i Now.WK[26];

(49) tak strašna/ prosto drošč jiz’e po skury jak čytaš ta ks'onžečka Now.WK[26];

(50) on $\boldsymbol{f}$ Pol'ski został Piet.AW[21];

(51) (Może Pani coś powie o swojej rodzinie?) o roz'iny/ nas była p'eńc' Piet.AW[21].

(52) na gospodarki rob’i Rom.RV[24];

(53) mus'i f čvartej kłasy byłam Szaw.WJ[34];

(54) była v G'irs'ax jakos'c'i škołal $f$ Šunełki Szuk.ZJ[23].

Analiza wymienionych wyżej przykładów pozwoliła zaobserwować pewne zależności między rodzajem spółgłoski kończącej temat fleksyjny a postacią miejscownika. Przedstawia je tabela nr 2. 
Tabela nr 2. Rodzaj spółgłoski tematycznej a różne formy miejscownika lp. rzeczowników żeńskich twardotematowych

\begin{tabular}{|c|c|c|c|c|}
\hline $\begin{array}{l}\text { Spółgłoska } \\
\text { tematyczna }\end{array}$ & $\begin{array}{l}\text { Ogp. alternacja } \\
+ \text { końc. -e z jej } \\
\text { wariantami } \\
\end{array}$ & $M s c=D$ & $\begin{array}{l}\text { Nogp. alternacja } \\
\text { w rzecz. na }-k-,-g_{-} \text {, } \\
-r-\end{array}$ & Razem \\
\hline$-k-$ & $70(56,9 \%)$ & $36(29,3 \%)$ & $17(13,8 \%)$ & 123 \\
\hline$-g-$ & $23(76,7 \%)$ & $4(13,3 \%)$ & $3(10 \%)$ & 30 \\
\hline$-\mathbf{r}-$ & $10(62,5 \%)$ & $5(31,25 \%)$ & $1(6,25 \%)$ & 16 \\
\hline$-n-$ & $54(90 \%)$ & $6(10 \%)$ & - & 60 \\
\hline$-\mathbf{m}-$ & $16(88,9 \%)$ & $2(11,1 \%)$ & - & 18 \\
\hline$-\mathrm{v}-$ & $54(100 \%)$ & - & - & 54 \\
\hline$-1-$ & $23(100 \%)$ & - & - & 23 \\
\hline$-t-$ & $29(100 \%)$ & - & - & 29 \\
\hline$-d-$ & $12(100 \%)$ & - & - & 12 \\
\hline$-p-$ & $1(100 \%)$ & - & - & 1 \\
\hline$-f-$ & $1(100 \%)$ & - & - & 1 \\
\hline$-s-$ & 0 & $1(100 \%)$ & - & 1 \\
\hline Razem & $293(79,6 \%)$ & $54(14,7 \%)$ & $21(5,7 \%)$ & 368 \\
\hline
\end{tabular}

Źródło: Opracowanie własne

$\mathrm{Z}$ danych zawartych $\mathrm{w}$ tabeli wynika, że końcówka $-y /-i$ pochodzenia dopełniaczowego poświadczona została najczęściej w rzeczownikach, których temat fleksyjny kończy się na spółgłoskę tylnojęzykową $k$ (36 przykładów, tj. 29,5\% wszystkich rzeczowników zakończonych w temacie fleksyjnym na tę spółgłoskę, a $66,7 \%$ całego zbioru osobliwych form miejscownika). Pojawiła się ona w następujących wyrazach: blaszka, butelka, chateczka, chatka, duchowka, garsteczka, gospodarka, kanapka, kłasa, ławeczka, ławka, maka, muzyka, pałka, podmurówka, ręka, rzeka, strojka, skrzypka, wioska/wiuska, w tym w nazwach własnych: Ameryka, Borówka, Polska, Szunełka. O wiele rzadziej występuje w rzeczownikach żeńskich twardotematowych zakończonych na spółgłoskę $g$ (4 przykłady, tj. 13,3\% wszystkich femininów twardotematowych z tematycznym -g-), np. noga, Ryga, spółgłoskę $r$ (5 przykładów, tj. 31,25\% rzeczowników zakończonych na tę spółgłoskę), por. gitara, kwatera, skóra, fura; spółgłoskę $n$ (6 egzemplifikacji, tj. 10\% rzeczowników z tematycznym - $n$-), por. leszczyna, rodzina, oraz $m$, por. mama (2 razy) i s, por. kłasa (1 raz). Są to głównie rzeczowniki rodzime, ale trafiają się także zapożyczenia, a więc rusycyzmy strojka, kłasa i białorutenizm duchowka.

Wyjątkowo taka forma Msc. lp. rzecz. żeńskich pojawiła się na Kowieńszczyźnie, por. v b'ibl'otek'i (Karaś 2002: 202). Odnotowałam ją jako jednostkową, sądząc, że 
może to być cecha idiolektalna. Tymczasem w badanych gwarach okolic Ignalina i Jeziorosów na Litwie stosunkowo liczne poświadczenia, łącznie 54 formy tego typu, każą widzieć zjawisko charakterystyczne nie tylko dla wybranego idiolektu. Warto podkreślić, że wystąpiły one u 26 informatorów, w tym u 11 respondentów z rejonu ignalińskiego i 15 z rejonu jezioroskiego. Nie jest to zatem zjawisko idiolektalne, ale charakteryzujące język znacznej części informatorów.

Badacze polszczyzny północnokresowej i południowokresowej nie notują takich form. Nie poświadcza ich Zofia Kurzowa w swojej monografii poświęconej językowi polskiemu na Wileńszczyźnie w XVI-XX wieku (Kurzowa 1993), ani badacze polszczyzny współczesnej na Kresach ${ }^{1}$ czy polszczyzny ludności przesiedlonej z Kresów Wschodnich (np. Lewaszkiewicz 2017).

Jaka jest zatem geneza tych form i synkretyzmu miejscownika - dopełniacza w obrębie deklinacji rzeczowników żeńskich twardotematowych?

Wydaje się, że złożyło się tu kilka przyczyn. Najłatwiej można wyjaśnić genezę miejscownikowych form na $-y$ równych dopełniaczowi lp. $w$ femininach twardotematowych, których temat fleksyjny kończy się na spółgłoskę -r-, gdyż w języku ogólnobiałoruskim końcówka -y występuje w Msc. lp. rzeczowników żeńskich nie tylko po spółgłoskach stwardniałych w deklinacji miękkotematowej, lecz także po spółgłosce $r$, por. np. błr. $\breve{y}$ кватэры 'w mieszkaniu'; на скуры 'na skórze', на zітары 'na gitarze'. Niemniej jednak ze względu na brak szerszego kontaktu z białoruskim językiem literackim (brak użycia go jako języka urzędowego, brak szkół białoruskich) wskazać należy raczej na oddziaływanie białoruszczyzny w wersji dialektalnej, podobnie jak i w odniesieniu do takich osobliwych form w rzeczownikach zakończonych na inną niż -r- spółgłoskę twardą (z wyjątkiem tylnojęzykowych $k, g$ ). W podgrupie północnej dialektu północno-wschodniego języka białoruskiego bliskiej badanemu obszarowi końcówkę -y przybierają bowiem nie tylko rzeczowniki z tematycznym -r-, jak w języku ogólnobiałoruskim i w jego odmianach gwarowych, lecz ogólnie rzeczowniki żeńskie z twardą podstawą w C. i Msc. lp., np. na s'c'any, u xaty (Barszczewska, Jankowiak 2012: 134), z wyjątkiem zakończonych na spółgłoski tylnojęzykowe. W związku z tym w języku białoruskim i w części gwar białoruskich (m.in. wskazanych wyżej) w odniesieniu do niektórych typów rzeczowników żeńskich twardotematowych, można mówić o synkretyzmie dopełniacza i miejscownika liczby pojedynczej.

Formy typu $w$ tej rzeki nie są natomiast bezpośrednim rezultatem interferencji białoruszczyzny. Geneza tych osobliwych miejscowników i synkretyzmu

1 Postać miejscownika lp. femininów twardotematowych została sprawdzona w wielu pracach, których wszystkich nie wymieniam, zwłaszcza w publikacjach poświęconych fleksji gwar wsi Zielona i Oleszkowce na Podolu Iwony Cechosz i Ewy Dzięgiel, pracach Sergiusza Rudnickiego, Janusza Riegera, Lidii Nepop, Barbary Dwilewicz, Jolanty Mędelskiej, Alojzego Zdaniukiewicza. 
miejscownika i dopełniacza lp. femininów twardotematowych - jak się wydaje - jest bardziej złożona. Po pierwsze, można widzieć tu wynik wyrównań analogicznych. Omówiony wyżej typ synkretyzmu mógł się rozpowszechnić drogą analogii w polszczyźnie północnokresowej podlegającej silnemu oddziaływaniu języka białoruskiego, zwłaszcza w jego odmianie dialektalnej, także na rzeczowniki zakończone na spółgłoski tylnojęzykowe. Jednak to przypuszczenie nieco osłabia mała liczba form miejscownika $z$ tematyczną spółgłoską twardą inną niż tylnojęzykowa tożsamych $\mathrm{z}$ dopełniaczem - zaledwie 13 form wobec $40 \mathrm{z}$ tematycznym $k, g$. Działanie analogii mogło być wsparte jednak w pewien sposób także wpływem wschodniosłowiańskim (rosyjskim i białoruskim). W gwarach białoruskich na obszarze ignalińskim i jezioroskim, które stanowią przedłużenie północnej grupy północno-wschodniego dialektu języka białoruskiego (Jankowiak 2016: 88, Karaś 2017: 48) w miejscowniku lp. rzeczowników żeńskich twardotematowych zakończonym w temacie fleksyjnym na $-k,-g$, tak jak i w języku rosyjskim, brak właściwych białoruszczyźnie alternacji tematycznych $k-c, g-z$, tj. brak palatalizacji $k, g, x$ (Barszczewska, Jankowiak 2012: 133). Występują tu natomiast oboczności $k-k^{\prime}, g-g^{\prime}$, np. на наге, на руке, tak jak w języku rosyjskim, przed końcówką -e, por. np. ros. в Америке 'w Ameryce', в реке 'w rzece', в ноге 'w nodze'. Na to mogła się nałożyć tendencja do wymowy nieakcentowanego $e$ jako $i / y$, stąd $v$ Ameryk'e $>v$ Ameryk'i, $v$ nog'e $>v$ nog'i. Pośrednio może o tym świadczyć przykład: $v$ Ryg’e/ $\boldsymbol{v}$ Rygi stužył Mag.MN[22]; w którym rosyjska i białoruska dialektalna z pochodzenia postać miejscownika v Ryg'e została następnie poprawiona na: $v$ Ryg'i. Zastanowić by się należało nad postacią miejscownika $w$ Polski, gdyż w języku białoruskim i rosyjskim różni się ona od pozostałych rzeczowników, nie kończy się na spółgłoskę tylnojęzykową (ros. Польma, błr. Польшча). Jak się wydaje, formą wyjściową mogła być tu forma miejscownika w Polskiej, wywodząca się z odmiany przymiotnikowej nazwy Polska, archaicznej, znanej do dziś na Kresach północnych (por. np. Karaś 2002, s. 205). Po zaniku wygłosowej joty powstała forma $f$ Polsk'e, poświadczona w uwzględnionych nagraniach, a wymowa nieakcentowanego $e$ jako $i$ mogła przyczynić się do pojawienia się miejscownikowej postaci $f$ Polsk'i, tożsamej z dopełniaczem. Jako potwierdzenie tego procesu może służyć następujący cytat z nagrań z okolic Jeziorosów: Smolvy byl 'i f Polsk'e / Turmonty f Polsk'ej Smołw.AS[39]. Formy typu $w$ tej butelki, $w$ tej rzeki, $w$ tej nogi mogą być więc rezultatem złożonych procesów interferencyjnych (fonetycznych i morfologicznych) oraz wyrównań analogicznych zachodzących w kontaktujących się językach.

Warto zbadać również, w jakich idiolektach pojawiają się omówione wyżej osobliwe formy miejscownika lp. rzeczowników żeńskich twardotematowych i czy można zauważyć jakąś prawidłowość w tym zakresie. Poniższe dwie tabele nr 3 i 4 przedstawiają zróżnicowanie idiolektalne analizowanych form lokatywnych. 
Tabela nr 3. Zróżnicowanie idiolektalne form miejscownika lp. rzeczowników żeńskich twardotematowych w polszczyźnie obszaru ignalińskiego

\begin{tabular}{|c|c|c|c|c|c|}
\hline Informator & $\begin{array}{l}\text { Liczba } \\
\text { form og- } \\
\text { p.z końc. } \\
-e\end{array}$ & $\begin{array}{l}\text { Liczba } \\
\text { kres.wa- } \\
\text { riantów } \\
\text { fon. końc. } \\
-e(-a,-i \text {, } \\
-y,-e\end{array}$ & $\begin{array}{l}\text { Liczba } \\
\text { form kres. } \\
\mathrm{z}-\mathrm{e} \text { bez } \\
\text { alternacji } \\
\text { tem. }\end{array}$ & $\begin{array}{l}\text { Liczba } \\
\text { form kre- } \\
\text { sowych } \\
\text { (Msc.=D.) }\end{array}$ & $\begin{array}{l}\text { Razem } \\
\text { formy Msc. } \\
\text { lp. rzecz. } \dot{z} \text {. } \\
\text { twardotem. }\end{array}$ \\
\hline Bej.IK[35] & 6 & 1 & 1 & 2 & 10 \\
\hline Czep.BD[24] & 5 & 5 & - & - & 10 \\
\hline Gaj.MK[25] & 2 & - & - & - & 2 \\
\hline Gaj.SK[26]] & 2 & 1 & - & - & 3 \\
\hline Gak.WP[12] & 7 & 1 & - & 1 & 9 \\
\hline Gram.MK[26] & 10 & 2 & 3 & - & 15 \\
\hline Mej.JS[42] & 2 & 2 & - & 2 & 6 \\
\hline Mej.TM[36] & 2 & 2 & - & 4 & 8 \\
\hline Pac.HS[25] & 13 & 1 & - & - & 14 \\
\hline Pruc.GS[26] & 2 & - & - & - & 2 \\
\hline Pruc.ZS[21] & 4 & 1 & - & - & 5 \\
\hline Pup.JU[34] & 3 & - & 1 & 2 & 6 \\
\hline Pusz.SK[23] & 5 & 1 & - & - & 6 \\
\hline Rej.WM[22] & 11 & 6 & - & - & 17 \\
\hline Rem.AC[29] & 4 & - & - & - & 4 \\
\hline Śmil.EP[15] & 0 & 1 & - & - & 10 \\
\hline Strył.KG[33] & 3 & - & 1 & - & 4 \\
\hline Strył.JG[34] & 3 & - & - & 1 & 4 \\
\hline Szmel.PL[19] & 6 & - & - & - & 6 \\
\hline Szuł.JS[33] & - & - & - & 1 & 1 \\
\hline Szuł.NK[30] & 7 & 2 & - & - & 9 \\
\hline Trycz.LT[32] & - & 1 & - & - & 1 \\
\hline Trykł.WS[32] & 2 & - & - & 1 & 3 \\
\hline Trykł.ZS[28] & - & 2 & 1 & 2 & 5 \\
\hline Und.HS[38] & 7 & - & - & 1 & 8 \\
\hline Weł.TS[35] & 6 & 6 & - & - & 12 \\
\hline Zyg.WT[34] & 3 & 1 & - & 1 & 5 \\
\hline Razem & $122(66,7 \%)$ & $36(19,7 \%)$ & $7(3,8 \%)$ & $18(9,8 \%)$ & $183(100 \%)$ \\
\hline
\end{tabular}

Źródło: Opracowanie własne 
Tabela nr 4. Zróżnicowanie idiolektalne form miejscownika lp. rzeczowników żeńskich twardotematowych w polszczyźnie obszaru jezioroskiego

\begin{tabular}{|c|c|c|c|c|c|}
\hline Informator & $\begin{array}{l}\text { Liczba } \\
\text { form og- } \\
\text { p.z końc. } \\
-e\end{array}$ & $\begin{array}{l}\text { Liczba } \\
\text { kres.wa- } \\
\text { riantów } \\
\text { fon. końc. } \\
-e(-a,-i \text {, } \\
-y,-e\end{array}$ & $\begin{array}{l}\text { Liczba } \\
\text { form kres. } \\
\mathrm{z}-e \text { bez } \\
\text { alternacji } \\
\text { tem. }\end{array}$ & $\begin{array}{l}\text { Liczba } \\
\text { form kre- } \\
\text { sowych } \\
\text { (Msc.=D.) }\end{array}$ & $\begin{array}{l}\text { Razem } \\
\text { formy Msc. } \\
\text { lp. rzecz. } \dot{z} \text {. } \\
\text { twardotem. }\end{array}$ \\
\hline Bach.JP[24] & 4 & 6 & - & 2 & 12 \\
\hline $\begin{array}{l}\text { Czepul. } \\
\text { KS[23] }\end{array}$ & 4 & - & - & - & 4 \\
\hline Duk.AS[46] & 7 & - & 2 & 1 & 10 \\
\hline Gir.AP[18] & 6 & 2 & - & 2 & 10 \\
\hline Grzeb.JN[31] & 1 & - & - & 3 & 4 \\
\hline Imb.WP[39] & 2 & 6 & 2 & 2 & 12 \\
\hline Jez.BK[30] & - & - & 1 & 2 & 3 \\
\hline Jez.JW[36] & 3 & 3 & - & 4 & 10 \\
\hline Kaln.IS[31] & 8 & 2 & - & 4 & 14 \\
\hline Mag.BP[31] & 3 & - & - & - & 3 \\
\hline Mag.JK[34] & 5 & 1 & 1 & - & 7 \\
\hline Mag.MN[22] & - & 2 & 1 & 4 & 7 \\
\hline Maz.SM[23] & - & 2 & - & 1 & 3 \\
\hline Min.JJ[35] & 2 & 2 & - & - & 4 \\
\hline Muk.JW[25] & 3 & 6 & 2 & - & 11 \\
\hline Nar.MS[20] & 1 & 2 & - & 1 & 4 \\
\hline Now.WK[26] & 10 & 3 & - & 5 & 18 \\
\hline Ows.AO[17] & 2 & 3 & - & - & 5 \\
\hline Piet.AW[21] & - & - & - & 2 & 2 \\
\hline Rom.RV[24] & 7 & - & - & 1 & 8 \\
\hline Smol.JW[27] & 6 & - & - & - & 6 \\
\hline Smołw.AS[39] & 8 & 1 & 3 & - & 12 \\
\hline Stal.JG[33] & 1 & 3 & - & - & 4 \\
\hline Suw.HK[29] & 1 & 3 & 2 & - & 6 \\
\hline Szaw.WJ[34] & 2 & - & - & 1 & 3 \\
\hline Szuk.HD[22] & 2 & - & - & - & 2 \\
\hline Szuk.ZJ[23] & - & - & - & 1 & 1 \\
\hline Razem & $88(47,5 \%)$ & $47(25,4 \%)$ & $14(7,6 \%)$ & $36(19,5 \%)$ & $185(100 \%)$ \\
\hline
\end{tabular}

Źródło: Opracowanie własne 
Analizowane próbki tekstów każdego idiolektu nie są duże - ok. 5-6 stron, dlatego też w zależności również od tematyki opowiadania form miejscownika rzeczowników żeńskich twardotematowych nie ma zbyt wiele. Najliczniej występują w tekstach informatorki z Nowików (Now.WK[26]) - 18, Rejbeni (Rej. WM[22]) - 17, Gramontyszek (Gram.MK[26]) - 15, Paciun (Pac.HS[25]) 14, Kalniszek (Kaln.IS[31]) - 14. Jednostkowe poświadczenia charakteryzują natomiast język informatorów z Szułan (Szuł.JS[33]), Tryczun (Trycz.LT[32]) i Szukiszek (Szuk.ZJ[23]).

Osobliwe formy miejscownika lp. tych rzeczowników pojawiają się w 27 idiolektach, na ogół obok form tożsamych z ogólnopolskimi czy też obok ich wariantów fonetycznych. Najwięcej takich form zawiera idiolekt informatorki z Mejszt (Mej.TM[36]) z rejonu ignalińskiego, a z rejonu jezioroskiego po 4 przykłady - idiolekty Jez.JW[36], Kaln.IS[31], Mag.MN[22], 5 przykładów - język informatorki z Nowików (Now.WK[26]). Nie zauważa się jednak wyłączności takich form, gdyż - co prawda - w języku 3 informatorów odnotowano tylko te formy osobliwe, ale są to poświadczenia pojedyncze pochodzące z małej próbki tekstowej (Szuł.JS[33], Piet.AW[21], Szuk.ZJ[23]). Uwzględnienie dłuższych tekstów zapewne dałoby nieco inne wyniki.

Widać, że częstsze są te postaci miejscownika w gwarach polskich rejonu jezioroskiego (prawie dwukrotnie) niż w rejonie ignalińskim. Można to wiązać z większą archaicznością odmiany jezioroskiej, determinowaną m.in. brakiem kontaktu z polszczyzną ogólną, na ogół brakiem polskiego szkolnictwa już w okresie międzywojennym na obszarze jezioroskim, podczas gdy w rejonie ignalińskim polszczyzna jako język urzędowy pełniła wszystkie możliwe funkcje. Mniejszą liczbę osobliwych form Msc. lp. tożsamych z D. lp. w rejonie ignalińskim i zarejestrowaną u mniejszej liczby osób niż w rejonie jezioroskim można zatem objaśniać wpływem nauczania po polsku jeszcze w okresie powojennym.

Bliższe przyjrzenie się biografii językowej informatorów, u których odnotowano omawiane osobliwe formy Msc. lp. rzeczowników żeńskich twardotematowych, i przede wszystkim próbkom ich tekstów wskazuje na większy niż u innych respondentów wpływ wschodniosłowiański. Potwierdzałoby to przedstawione wyżej przyczyny pojawienia się osobliwego synkretyzmu miejscownika i dopełniacza lp. rzeczowników żeńskich twardotematowych w badanych gwarach polskich pogranicza litewsko-łotewsko-białoruskiego. 


\section{Wnioski}

1. W zbiorze 368 form miejscownika lp. rzeczowników żeńskich twardotematowych zakończonych na -a dominują formy zgodne z polszczyzną ogólną, a więc $\mathrm{z}$ końcówką -e lub jej wariantami fonetycznymi $-a,-a,-i /-y$ oraz odpowiednimi alternacjami tematycznymi.

2. Liczba osobliwych form miejscownika, synkretycznych z dopełniaczem nie jest zbyt duża - 54 formy zarejestrowane w 27 idiolektach, co stanowi 14,7\% wszystkich form lokatywnych. Występują one częściej (dwukrotnie) w gwarach polskich rejonu jezioroskiego niż $w$ rejonie ignalińskim. Częściej też te formy charakteryzują idiolekty mocniej nasycone wpływami wschodniosłowiańskimi.

3. Interferencja białoruskich gwar północno-wschodnich zaznacza się w rzeczownikach żeńskich twardotematowych, które przybierają w polszczyźnie lokalnej, podobnie jak we wskazanych gwarach białoruskich, w Msc. lp. końcówkę $-y$, co skutkuje synkretyzmem miejscownika i dopełniacza tych rzeczowników, stąd formy $v$ roz’iny, na leščyny, pšy mamy, na kvatery, na svojej skury.

4. Wyrównania analogiczne, interferencja gwar białoruskich i zarazem proces fonetyczny (wymowa nieakcentowanej końcówki -e jako -i po spółgłoskach zmiękczonych $k^{\prime}, g^{\prime}$ ) mogą być przyczyną najliczniejszych w zebranym materiale osobliwych form miejscownika lp. tożsamych $\mathrm{z}$ dopełniaczem rzeczowników zakończonych na spółgłoskę tylnojęzykową, a więc typu $f$ tej žek $i, f$ tej xatečk $i$, po butelk'i, na tej nog'i.

5. Oddziaływanie gwar białoruskich pasa północno-wschodniego i języka rosyjskiego widoczne jest $\mathrm{w}$ rzeczownikach zakończonych na $-k-$-, $-g-$, w których w części przykładów brak właściwych im alternacji będących rezultatem palatalizacji tych spółgłosek, stąd formy typu na tačk'e, na gurk'e, pšy curk'e, $v$ R'ig'e.

\section{Bibliografia}

Ананева Наталья, 1974, Морфологические чередования в польском говоре деревни Гайде Игналинского района Литовской ССР, „Вестник Московского Государственного Университета”, серия 10. Филология, т. 1, с. 50-58.

Ананева Наталья, 1983, Некоторые особенности фонетической интерференции у полилингвов одного периферийного польского говора, „Studia nad Polszczyzną Kresową", t. 2, s. 65-72.

Ананева Наталья, 1983, Чередования в парадигме настоящего времени глаголов польского говора деревни Гайде Игналинского района Литовской ССР, „Studia nad Polszczyzną Kresową", t. 1, s. 179-193.

Barszczewska Nina, Jankowiak Mirosław, 2012, Dialektologia białoruska, Warszawa. 
Giułumianc Kira, Czekman Valerijus (1971). Polska gwara m. Widze i okolicy (na substracie białorusko-litewskim), „Slavia Orientalis”, t. 3, s. 313-325.

Jankowiak Mirosław, 2016, Współczesne gwary białoruskie na wschodniej Litwie (rejony ignaliński i święciański), „Slavistica Vilnensis”, t. 61, 81-105.

Karaś Halina, 2001, O sytuacji języka polskiego na tzw. obszarze smołwieńskim na Litwie, „Prace Filologiczne”, t. 46, 267-292.

Karaś Halina, 2002, Gwary polskie polskie na Kowieńszczyźnie, Warszawa-Puńsk.

Karaś Halina, 2004, O polszczyźnie wokół Jeziorosów na Litwie,,Studia nad Polszczyzną Kresową", t. 11, s. 35-72. Warszawa.

Karaś Halina, 2009, Polszczyzna okolic Jeziorosów jako wariant terytorialny języka polskiego na Litwie, [w:] Ewa Dzięgiel, Anna Zielińska (red.), Polszczyzna za granicą jako język mniejszości i języki mniejszościowe w Polsce, s. 25-46, Warszawa.

Karaś Halina, 2013a, O badaniach sytuacji i stanu polszczyzny na Litwie na pograniczu litewsko-łotewsko-białoruskim, „Prace Filologiczne”, t. 64, cz. 1, s. 111-127.

Karaś Halina, 2013b, Uwagi o leksyce polszczyzny na Litwie na pograniczu litewsko-łotewsko-białoruskim, „Acta Baltico-Slavica”, 37, s. 359-382.

Karaś Halina, 2017, Język polski pogranicza litewsko-łotewsko-białoruskiego w świetle frekwencji cech językowych, Warszawa.

Kardelis Vytautas, 2016, Języki i ich funkcjonowanie na terenie Litwy Wschodniej, [w:] Krystyna Rutkowska (red.), Gwary polskie na Litwie. Przewodnik multimedialny po gwarach polskich na Litwie, http://www.lenkutarmes.flf.vu.lt/apie/straipsniai (dostęp 28.04.2019).

Kurzowa Zofia, 1993, Język polski Wileńszczyzny i kresów północno-wschodnich XVIXX w., Warszawa-Kraków.

Lewaszkiewicz Tadeusz, 2017, Język powojennych przesiedleńców z Nowogródka i okolicy, Poznań.

Rutkowska Krystyna, 2004, Lituanizmy leksykalne w gwarach polskich na obszarze ignalińsko-jezioroskim, „Prace Filologiczne”, t. 49, s. 427-436.

Rutkowska Krystyna, 2013, Interferencje litewskie i wschodniosłowiańskie w gwarach polskich na obszarze ignalińskim na Litwie, „Prace Filologiczne”, t. 64, s. 303-318.

Rutkowska Krystyna, 2015, Lituanizmy w gwarach polskich pogranicza litewsko-łotewsko-białoruskiego, [w:] Barbara Falińska, Halina Karaś (red.), Studia gwaroznawcze 2, s. 155-169, Łomża.

Turska Halina, 1939/1995, O powstaniu polskich obszarów językowych na Wileńszczyźnie, Valerijus Čekmonas (oprac.), Vilnius.

\section{Wykaz skrótów oznaczających informatorów}

Bach.JP[24] - kobieta, ur. w 1924 r. w Bachmatach i tam zamieszkała, lit. Bachmatai pol. Bachmaty, rejon jezioroski.

Bej.IK[35] - kobieta, ur. w 1935 r. w pobliskich Lalupach, mieszka w Bejkielach, lit. Baikeliai - pol. Bejkiele, gmina daugieliska, rejon ignaliński.

Bort.HC[35] - kobieta ur. w 1935 r. w Bortkiszkach i tam mieszka, lit. Bartkiškè - pol. Bortkiszki, rejon jezioroski. 
Czep.BD[24] - kobieta, ur. w 1924 r. w pobliskich Berżenikach, mieszka w Czepukanach, lit. Čepukai - pol. Czepukany, gmina rymszańska, rejon ignaliński.

Czepul.KS[23] - kobieta, ur. w 1923 r., mieszka w Czepuliszkach, lit. Čepuliškiai - pol. Czepuliszki, rejon jezioroski.

Duk.AS[46] - mężczyzna, ur. w 1946 r. w Dukiszkach i tam zamieszkały, lit. Dukiškès - pol. Dukiszki, rejon jezioroski.

Gaj.MK[25] - kobieta, ur. w Gajdach w 1925 r., żona informatora Gaj.SK[26], mieszka cały czas w Gajdach, lit. Gaidai - pol. Gajdy, rejon ignaliński.

Gaj.SK[26] - mężczyzna, ur. w 1926 r. w sąsiedniej wsi, mąż informatorki Gaj.MK[25], mieszka w Gajdach, lit. Gaidai - pol. Gajdy, rejon ignaliński.

Gak.WP[12] - kobieta, ur. w 1912 r. w Gakianach i tam całe życie mieszkała, lit. Gakènai - pol. Gakiany, rejon ignaliński.

Gir.AP[18] - kobieta, ur. w 1918 r., mieszka w Girsiach, lit. Girsiai - pol. Girsie, rejon jezioroski.

Gram.MK[26] - kobieta ur. w 1926 r. w Szułanach, mieszka w Gramontyszkach, lit. Gramantiškè - pol. Gramontyszki (tak w wykazach przedwojennych) / Gramonciszki (wersja polska nazwy podana przez informatorów), gmina rymszańska, rejon ignaliński.

Grzeb.JN[31] - kobieta, ur. w 1931 r. w Grzebieniszkach i tam zamieszkała, lit. Grebeniškès - pol. Grzebieniszki, rejon jezioroski.

Imb.WP[39] - kobieta, ur. w 1939 r. we wsi Niedożynki koło Stalmujży, od chwili zamążpójścia mieszka w Imbrodach, lit. Imbradas - pol. Imbrody, rejon jezioroski. Jez.BK[30] - mężczyzna, ur. w 1930 w pobliskich Szukiszkach, mieszka w Jeziorosach, lit. Zarasai - pol. Jeziorosy, rejon jezioroski.

Jez.JW[36] - kobieta, ur. w 1936 r. w Dukiszkach (ok. 4 km od Jeziorosów), mieszka w Jeziorosach, lit. Zarasai - pol. Jeziorosy, rejon jezioroski.

Kaln.IS[31] - kobieta, ur. w 1931 r. w Połciszkach koło Dukszt, mieszka w Kalniszkach, lit. Kalniškè - pol. Kalniszki, gmina smołwieńska, rejon jezioroski.

Mag.BP[31] - kobieta, ur. w 1931 r. w Czepukiszkach, mieszka w Maguciach, lit. Magučiai - pol. Magucie, rejon jezioroski.

Mag.JK[34] - kobieta, ur. w 1934 r. w Epidemiszkach koło Jeziorosów, mieszka w Maguciach, lit. Magučiai - pol. Magucie, rejon jezioroski.

Mag.MN[22] - kobieta, ur. w 1922 r. w Galiniszkach, mieszka w Maguciach, lit. Magučiai - pol. Magucie, rejon jezioroski.

Maz.SM[23] - kobieta, ur. w 1923 r. w Mazurkach i tam mieszka, lit. Mozurèliai - pol. Mazurki, rejon jezioroski.

Mej.JS[42] - mężczyzna, ur. w 1942 r. w Boguszyszkach, mąż informatorki Mej.AS[44], mieszka od 1950 roku w Mejsztach, lit. Meikštai - pol. Mejszty, rejon ignaliński.

Mej.TM[36] - kobieta ur. w 1936 r. w Gierwaniszkach, mieszka w Mejsztach od czasów melioracji, tj. od r. 1970, lit. Meikštai - pol. Mejszty, rejon ignaliński.

Min.JJ[35] - mężczyzna, ur. w 1935 r., mąż informatorki Min.KJ[37], mieszka w Minówce, lit. Minauka - pol. Minówka, rejon jezioroski.

Muk.JW[25] - kobieta, ur. w 1925 r. we wsi Łeki, mieszka w Mukulach, lit. Mukuliai pol. Mukule, rejon jezioroski. 
Nar.MS[20] - kobieta, ur. w 1920 r. w Ratuliszkach w gminie Imbrody, od 1949 roku mieszka w Narsuniszkach, lit. Narsūniškès - pol. Narsuniszki, rejon jezioroski.

Now.WK[26] - kobieta, ur. w 1926 r., mieszka w Nowikach, lit. Novikai - pol. Nowiki, rejon jezioroski.

Ows.AO[17] - kobieta, ur. w 1917 r. w Jeziorosach, mieszka w Owsłach 57 lat, lit. Auslas - pol. Owsły, rejon jezioroski.

Pac.HS[25] - kobieta, ur. w 1925 r. w Paciunach, mieszka w tej wsi całe życie, lit. Pociūnai - pol. Paciuny, rejon ignaliński.

Piet.AW[21] - kobieta, ur. w 1921 r. w Stalmujży, w Pietruniszkach mieszka od 24 lat, lit. Petruniškis - pol. Pietruniszki, rejon jezioroski.

Pruc.GS[26] - kobieta, ur. w 1926 r., żona informatora Pruc.ZS[21], mieszka w Pruciach, lit. Prūčiai - pol. Prucie, rejon ignaliński.

Pruc.ZS[21] - mężczyzna, ur. w 1921 r. w Leningradzie, został jako niemowlę przywieziony do Pruci, mieszka tu całe życie, lit. Prūčiai - pol. Prucie, rejon ignaliński. Mąż informatorki Pruc.GS[26].

Pup.JU[34] - kobieta, ur. w 1934 r. w pobliskiej wsi, mieszka od 1955 r. w Pupiniach, lit. Pupiniai - pol. Pupinie, rejon ignaliński.

Pusz.SK[23] - kobieta, ur. w 1923 we wsi Wojciszki położonej 1,5 km od Puszek, w latach 60. XX w. przeniosła się do Puszek i tu mieszka, lit. Pūškos - pol. Puszki, rejon ignaliński.

Rej.WM[22] - kobieta, ur. w 1922 r. w pobliskich Bejkielach, od zamążpójścia mieszka w Rejbeniach, lit. Raibeniai - pol. Rejbenie, gmina Nowe Daugieliszki, rejon ignaliński.

Rem.AC[29] - kobieta, ur. w 1929 r. w pobliskiej wsi Janowo, po wyjściu za mąż w 1958 roku zamieszkała w Remejkach, lit. Rameikos - pol. Remejki, rejon ignaliński.

Rom.RV[24] - mężczyzna, ur. w 1924 r. w Romańcach i tam mieszka, lit. Romancai pol. Romańce, gmina Jeziorosy, rejon jezioroski,

Smoł.JW[27] - kobieta, ur. w 1927 r. w pobliskich Suntupiach (3 km od Smołw), mieszka w Smołwach, lit. Smalvos - pol. Smołwy, rejon jezioroski.

Smołw.AS[39] - kobieta, ur. w 1939 r., mieszka w Smołweczkach, lit. Smalvelès - pol. Smołweczki, rejon jezioroski.

Stal.JG[33] - kobieta, ur. w 1933 r. w Stalmujży i tam mieszka, lit. Stelmužè - pol. Stalmujża (Stelmuże - według informatorów), rejon jezioroski.

Strył.JG[34] - mężczyzna, ur. w 1934 r. w Stryłungach i tam mieszka, mąż informatorki Strył.KG[33], lit. Strilungiai - pol. Stryłungi, rejon ignaliński.

Strył.KG[33] - kobieta, ur. w 1933 r. we wsi Gierwieniszki, od 1965 r. mieszka w Stryłungach, żona informatora Strył.JG[34], lit. Strilungiai - pol. Stryłungi, rejon ignaliński.

Suw.HK[39] - kobieta, ur. w 1929 r. w Pobołciach (lit. Pabalte) za Dusiatami, mieszka w Suwiekach, lit. Suviekas - pol. Suwieki, rejon jezioroski.

Szaw.WJ[34] - kobieta, ur. w 1934 r. w pobliskich Rutach, od zamążpójścia mieszka w Szawlach, lit. Šauliai - pol. Szawle, rejon jezioroski.

Szmel.PL[19] - kobieta, ur. w 1919 r. w pobliskich Bieniaszach (wieś opuszczona, nikt już tam nie mieszka), od 1940 r. mieszka w Szmelach, lit. Smèliai - pol. Szmele, rejon ignaliński. 
Szuk.HD[22] - kobieta, ur. w 1922 r. w Łekach, mieszka w Szukiszkach 59 lat, lit. Šukiškès - pol. Szukiszki, rejon jezioroski.

Szuk.ZJ[23] - kobieta, ur. w 1923 r. w Szukiszkach i tu mieszka całe życie, lit. Šukiškès - pol. Szukiszki, rejon jezioroski.

Szuł.JS[33] - kobieta, ur. w 1933 r. w Zygmunciszkach koło Mejszt, mieszka w Szułanach od czasów melioracji (lata 70. XX wieku), lit. Šiulènai - pol. Szułany, rejon ignaliński.

Szuł.NK[30] - kobieta ur. w 1930 r., mieszka w Szułanach, lit. Šiulènai - pol. Szułany, rejon ignaliński

Śmil.EP[15] - mężczyzna, ur. w 1915 r. w pobliskich Daugieliszkach, mieszka w Śmilginiszkach od dzieciństwa, lit. Smilginiškè - pol. Śmilginiszki, rejon ignaliński.

Trycz.LT[32] - kobieta, ur. w 1932 r., mieszka w Tryczunach, lit. Tryčiūnai - pol. Tryczuny (inna wersja nazwy: Traczuny), rejon ignaliński.

Trykł.WS[32] - kobieta, ur. w 1932 r., żona informatora Trykł.ZS[28], mieszka w Trykłaciszkach, lit. Triklotiškè - pol. Trykłaciszki, rejon ignaliński.

Trykł.ZS[28] - mężczyzna, ur. w 1928 r., pracował całe życie jako stolarz, mąż informatorki Trykł.WS[32], mieszka w Trykłaciszkach, lit. Triklotiške - pol. Trykłaciszki, rejon ignaliński.

Und.HS[38] - kobieta, ur. w 1938 r. w Undrełanach i tu mieszka, żona informatora Und. WS[33], lit. Andrelènai - pol. Undrełany, rejon ignaliński.

Weł.TS[35] - kobieta, ur. w 1935 roku koło Mejszt, w Wełunach mieszka od zamążpójścia, lit. Vèlunai - pol. Wełuny (Wieluny - tak w SGKP), rejon ignaliński.

Zyg.WT[34] - kobieta, ur. w 1934 r. w Zygmunciszkach i tam mieszka, lit. Žygmantiškè pol. Zygmunciszki, rejon ignaliński.

\section{Streszczenie}

Przedmiot opisu stanowią w niniejszym artykule formy miejscownika liczby pojedynczej rzeczowników żeńskich twardotematowych występujące w gwarach polskich na Litwie w rejonach ignalińskim i jezioroskim graniczących z Białorusią i Łotwą, a w szczególności nieopisane w literaturze przedmiotu, nieznane na innych obszarach gwarowych na Litwie formy miejscownika synkretyczne $\mathrm{z}$ dopełniaczem, typu $w$ tej rzeki, pierwszy w rodziny, na swojej skóry. W artykule przedstawiono genezę tych osobliwości, ich frekwencję, liczebność i uwarunkowania idiolektalne. 